\title{
A PROPOSITION ON CRACK INITIATION EVALUATION USING STRESS TRIAXIALITY AND LOCAL DUCTILITY
}

\author{
応力三軸度と局部延性を用いた亀裂発生評価の提案
}

\author{
Wu-Bo QI* and Hiroaki MIMURA** \\ 戚 務 柏, 見村博明
}

\begin{abstract}
As a result of extensive researches, stress triaxiality ratio and local ductility were found deeply associated with crack initiation in the welded beam-column connections. When considering whether current definition of the relationship between triaxiality and local ductility can be used for judging, evaluating and predicting crack initiation behavior of the welded beam-column connections, it unfortunately turns out a difficulty to satisfy such a purpose. In this paper, emphasis at the beginning is to establish a new relationship between stress triaxiality and local ductility using the strain incremental theory. FEM analysis then is conducted to determine the critical value of crack initiation with the help of data collected from the full-scaled connection subassembly tests. For a better understanding of the new definition, detailed information on how to judge, evaluate and predict the likelihood of crack initiation mode as well as connection load-bearing ability is provided.
\end{abstract}
Keywords: welded beam-column connection, 柱一はり溶接接合部,
stress triaxiality,
応力三軸度,
local ductility, 局部延性,
rupture index
破壊指数

\section{INTRODUCTION}

Demanded for preventing brittle fracture reoccurrences of the welded beam-column connections in the Northridge and Kobe earthquakes, extensive researches to investigate what attributes associated with crack initiation showed that stress triaxiality ratio and local ductility were deeply concerned in (El-Tawil et al. 2000; Schafer et al. 2000).

Stress triaxiality $(\tau)$, briefly called triaxiality, is an important quantity because studies on micro-scale fracture mechanism show that nucleation, growth and coalescence of the micro-scale voids are dependent on it (McClintock 1967; Rice and Tracey 1969). When considering ductile rupture of metals, a high triaxiality can cause rapid damage accumulation as well as a large reduction in rupture strain thereby limiting ductility (Barsom and Rolfe 1987; Lemaitre 1996). The plastic flow ability of a point of interest in connections is an important property because it limits the high stress that would otherwise be produced therefore reduces a propensity of brittle fracture.

As a trend developed in Japan, ductile crack initiation evaluations using stress triaxiality and local ductility have been emphasized. Kuwamara et al. experimentally investigated critical strain affected by cold-working as well as geometrical size (1994) when ductile crack initiated. They suggested an empirical crack initiation criterion for round bars under a triaxiality state (1995); Ohata and An et al. (2000-2001) concentrated their efforts to study parameter-effects from strength mismatch and cyclic/dynamic loading. Test results showed that critical ductile crack initiation in round bars was independent of strength mismatch as well as cyclic/dynamic loading when parameters of equivalent plastic strain and stress triaxiality were employed to analyze their data.

For an interest, it is worth identifying whether current definitions of the relationship between triaxiality and local ductility can be also used for judging, evaluating and predicting crack initiation of the welded beam-column connections. As demonstrated in the following sections, current definition is found difficult to satisfy such a purpose. As a solution, stress at the beginning of this paper is to establish a new definition of relationship between stress triaxiality and local ductility using the strain incremental theory. FEM analysis then is conducted to determine the critical value of crack initiation at key points with the help of data collected from the full-scaled connection subassembly tests. For a better understanding of the new definition, detailed information on how to judge, evaluate and predict the likelihood of crack initiation mode as well as connection.

\footnotetext{
${ }^{*}$ Research Fellow, Department of Civil and Environmental Engineering, Tokyo 東京電機大学 研究員 · 工修 Denki University, M. Eng. ** Prof., Department of Civil and Environmental Engineering, Tokyo Denki 東京電機大学 教授.工博
University, Dr. Eng.
} 
load-bearing ability is finally provided.

\section{EXISTING DEFINITION OF RELATIONSHIP BETWEEN TRIAXIALITY AND LOCAL DUCILITY}

Triaxiality is often discussed in relation to multiaxial state of stresses that are accompanied by large principal stresses. It is usually defined as the hydrostatic stress $\sigma_{\mathrm{H}}$ divided by the Von Mises stress $\sigma_{e}$

$$
\tau=\frac{\sigma_{\mathrm{H}}}{\sigma_{\mathrm{c}}}
$$

in which $\sigma_{\mathrm{H}}$ and $\sigma_{\mathrm{e}}$ are defined respectively as

$$
\begin{gathered}
\sigma_{\mathrm{H}}=\frac{1}{3}\left(\sigma_{1}+\sigma_{2}+\sigma_{3}\right) \\
\sigma_{\mathrm{e}}=\left[\frac{1}{2}\left\{\left(\sigma_{1}-\sigma_{2}\right)^{2}+\left(\sigma_{1}-\sigma_{3}\right)^{2}+\left(\sigma_{2}-\sigma_{3}\right)^{2}\right\}\right]^{\frac{1}{2}}
\end{gathered}
$$

where $\sigma_{1}, \sigma_{2}$ and $\sigma_{3}$ are principal stresses. Subscript $e$ and subscript $H$ denote equivalent stress and hydrostatic stress respectively.

A typical index used to measure the local ductility is PEEQ index, which is defined as plastic equivalent strain $\varepsilon_{\mathrm{e}}{ }^{\mathrm{p}}$ divided by yield strain $\varepsilon_{y}$ (El-Tawil et al. 2000)

$$
\mathrm{PEEQ}=\frac{\varepsilon_{\mathrm{e}}^{\mathrm{p}}}{\varepsilon_{\mathrm{y}}}
$$

in which $\varepsilon_{y}$ is the yield strain of the material used at the point of interest; $\varepsilon_{\mathrm{e}}^{\mathrm{p}}$, the extent of plastic flow, usually is expressed as

$$
\varepsilon_{e}{ }^{p}=\left[\frac{2}{9}\left\{\left(\varepsilon_{1}{ }^{p}-\varepsilon_{2}{ }^{p}\right)^{2}+\left(\varepsilon_{1}{ }^{p}-\varepsilon_{3}{ }^{p}\right)^{2}+\left(\varepsilon_{2}{ }^{p}-\varepsilon_{3}{ }^{p}\right)^{2}\right\}\right]^{\frac{1}{2}}
$$

In 2000, El-Tawil et al. defined an exponential relationship between triaxiality and local ductility by rupture index (RI), which is written as

$$
\text { Rupture Index }=\frac{\text { PEEQ }}{\exp (-1.5 \tau)}
$$

Such an index was reported effective to indicate potential fracture propensities for various configured subassemblies at their key points. It is worth noting that Eq.(2.6) was originally defined by Rice and Tracey (1969), who assumed a dilatation amplification $D$ to search an approximate solution for surface integrals related to growth of a spherical void in a uniaxial tension strain rate field.

$$
D=\mathrm{c}(\mathrm{u}) \exp \left(\frac{\sqrt{3} \sigma^{\infty}}{2 \tau_{0}}\right)
$$

in which, $c(v)$ is a material constant and $\sigma^{\infty} / \tau_{0}$ is equivalent to the triaxiality defined in Eq.(2.1). In 1976, Hancock and Mackenzie modified Eq.(2.7) and obtained an approximate failure criterion based on a premise that the failure strain was inversely proportional to hole growth-rate,

$$
\varepsilon_{\mathrm{f}}=\alpha \cdot \exp (-1.5 \tau)
$$

where $\varepsilon_{f}$ is the failure strain, $\alpha$ is a material-dependent constant. El-Tawil et al. modified Eq.(2.8) and obtained Eq.(2.6).

From the above descriptions, an important point can be made that there could have a criterion that can be used for evaluating macro-scale crack initiation therefore without considering too much of mechanics of micro-scale void growth and void coalescence. Such a criterion is assumed associated with material itself, independent of external limits such as overall specimen size and test facilities etc. As a consequence, Eq.(2.6) is firstly investigated to see whether it can satisfy such a demand. However, as demonstrated in section 5, Eq.(2.6) turns out a large scattering therefore fails to evaluate crack initiation for various configured connection subassemblies.

For a solution, it is necessary to reinvestigate the relationship between triaxiality and PEEQ index.

\section{NEW DEFINITON OF RELATIONSHIP BETWEEN TRIAXIALIY AND PEEQ INDEX}

For any given point of interest within a subassembly, which is constricted to behave within a small deformation, the principal stresses always satisfy the Hook's law. In detail, they are

$$
\begin{aligned}
& \sigma_{1}=\frac{E}{1+v}\left[\left(\varepsilon_{1}+\frac{\nu}{1-2 \nu}\left(\varepsilon_{1}+\varepsilon_{2}+\varepsilon_{3}\right)\right]\right. \\
& \sigma_{2}=\frac{E}{1+\nu}\left[\left(\varepsilon_{2}+\frac{\nu}{1-2 \nu}\left(\varepsilon_{1}+\varepsilon_{2}+\varepsilon_{3}\right)\right]\right. \\
& \sigma_{3}=\frac{E}{1+\nu}\left[\left(\varepsilon_{3}+\frac{v}{1-2 \nu}\left(\varepsilon_{1}+\varepsilon_{2}+\varepsilon_{3}\right)\right]\right.
\end{aligned}
$$

in which, $\sigma_{1}, \sigma_{2}, \sigma_{3}$ and $\varepsilon_{1}, \varepsilon_{2}, \varepsilon_{3}$ are principal stresses and principal strains respectively. $E$ is the Young's modulus and $v$ is the Poisson ratio. Combining Eqs. (3.1) (3.3) reduces to

$$
\sigma_{\mathrm{H}}=\frac{1}{3}\left(\sigma_{1}+\sigma_{2}+\sigma_{3}\right)=\frac{E}{3(1-2 \nu)}\left(\varepsilon_{1}+\varepsilon_{2}+\varepsilon_{3}\right)=\frac{E}{3(1-2 \nu)} \xi=K \xi
$$

Here $\xi$ is defined as volume dilatation and $K$ is known as bulk modulus. Eq.(3.4) indicates that $\xi$ equals to $\varepsilon_{r}+\varepsilon_{2}+\varepsilon_{3}$, the first invariant of strain, which is coordinate independent.

To any point of interest, if the material considered is assumed to be homogeneous and isotropic, plastically flow in accordance with the Prandle-Reuss rule, we always have

$$
\frac{\mathrm{d} \varepsilon_{1}^{\mathrm{p}}}{\sigma_{1}^{\prime}}=\frac{\mathrm{d} \varepsilon_{2}^{\mathrm{p}}}{\sigma_{2}^{\prime}}=\frac{\mathrm{d} \varepsilon_{3}^{\mathrm{p}}}{\sigma_{3}^{\prime}}=\frac{3 \mathrm{~d} \varepsilon_{\mathrm{e}}^{\mathrm{p}}}{2 \sigma_{\mathrm{e}}}=\mathrm{d} \lambda=\frac{3 \mathrm{~d} \sigma_{\mathrm{e}}}{2 \mathrm{H}_{\mathrm{e}}}
$$

and

$$
\begin{aligned}
& \mathrm{d} \varepsilon_{1}{ }^{t}=\frac{1}{E} d\left[\left(\sigma_{1}-v\left(\sigma_{2}+\sigma_{3}\right)\right]+\sigma_{1}{ }^{\prime} d \lambda\right. \\
& d \varepsilon_{2}{ }^{t}=\frac{1}{E} d\left[\left(\sigma_{2}-v\left(\sigma_{1}+\sigma_{3}\right)\right]+\sigma_{2} d \lambda\right. \\
& d \varepsilon_{3}{ }^{t}=\frac{1}{E} d\left[\left(\sigma_{3}-v\left(\sigma_{1}+\sigma_{2}\right)\right]+\sigma_{3} d \lambda\right.
\end{aligned}
$$

in which, $\sigma_{1}{ }^{\prime}, \sigma_{2}{ }^{\prime}$ and $\sigma_{3}{ }^{\prime}$ are deviate stresses and $\sigma_{1}{ }^{\circ}+\sigma_{2}{ }^{\circ}+\sigma_{3}$ equals to zero; $\lambda$ and $\mathrm{H}^{\prime}$ are known as material constant and strain hardening rate respectively (Taira 1976). To distinguish current principal strains $\varepsilon_{1}{ }^{t}, \varepsilon_{2}{ }^{t}$ and $\varepsilon_{3}{ }^{t}$ from the elastic ones $\varepsilon_{1}, \varepsilon_{2}$ and $\varepsilon_{3}$ used in Eqs.(3.1) (3.3), superscript $t$ is employed, in which $t$ denotes the total stain.

Combining Eqs. (3.6) $\sim(3.8)$ leads to

$$
\mathrm{d}\left(\varepsilon_{1}{ }^{\mathrm{t}}+\varepsilon_{2}{ }^{\mathrm{t}}+\varepsilon_{3}{ }^{\mathrm{t}}\right)=\frac{3(1-2 v)}{\mathrm{E}} \mathrm{d} \sigma_{\mathrm{H}}+\left(\sigma_{1}{ }^{1}+\sigma_{2}{ }^{2}+\sigma_{3}\right) \mathrm{d} \lambda
$$

Noted that $\sigma_{1}{ }^{\prime}+\sigma_{2}{ }^{\prime}+\sigma_{3}{ }^{\prime}$ equals to zero and as long as an incompressible material concerned, the plastic incremental component $\varepsilon_{1}{ }^{\mathrm{p}}+\varepsilon_{2}{ }^{\mathrm{p}}+\varepsilon_{3}{ }^{\mathrm{p}}$ contained in $\varepsilon_{1}{ }^{\mathrm{t}}+\varepsilon_{2}{ }^{\mathrm{t}}+\varepsilon_{3}{ }^{\mathrm{t}}$ generally, is considered having no contribution to volume dilatation. The total volume dilatation therefore can be regarded as a result of accumulated elastic deformation. Consequently, superscript $t$ is eliminated and Eq.(3.9) is rewritten as

$$
\mathrm{d}\left(\varepsilon_{1}+\varepsilon_{2}+\varepsilon_{3}\right)=\frac{3(1-2 v)}{\mathrm{E}} \mathrm{d} \sigma_{\mathrm{H}}
$$

Comparing Eq.(3.10) with Eq.(3.4), we know that Eq.(3.10) is virtually identical to Eq.(3.4). In other words, Eq.(3.4) can be applied to evaluate the point of interest that deforms elastically 
and plastically.

Now consider a case when $P E E Q$ has an infinitesimal increment $d(P E E Q \overline{)})$. According to Eq.(2.4), we have

$$
d(P E E Q)=\frac{1}{\varepsilon_{\mathrm{y}}} d \varepsilon_{e}^{p}
$$

Noted that we have a relationship between $d \varepsilon_{\mathrm{e}}{ }^{p}$ and $d \sigma_{\mathrm{e}}$ defined in Eq.(3.5), substituting this relationship into Eq.(3.11) gives to

$$
d(P E E Q)=\frac{1}{H^{\prime} \varepsilon_{\mathrm{y}}} d \sigma_{e}
$$

Integrate Eq.(3.12) on both sides,

$$
\int_{0}^{\text {PEEQ }} \mathrm{d}(\mathrm{PEEQ})=\frac{1}{\mathrm{H}_{\mathrm{y}}^{\prime}} \int_{0}^{\sigma_{\varepsilon}} \mathrm{d} \sigma_{e}
$$

which leads to

$$
\mathrm{PEEQ}=\frac{\sigma_{c}}{H \varepsilon_{y}}
$$

By Eq.(2.1), $\sigma_{\mathrm{e}}$ can be written as

$$
\sigma_{\mathrm{e}}=\frac{\sigma_{\mathrm{H}}}{\tau}
$$

Substituting Eq.(3.15) into Eq.(3.14) gives to

$$
\tau \text {.PEEQ }=\frac{\sigma_{H}}{H \cdot \varepsilon_{y}}
$$

Remember that Eq.(3.4) could be used to evaluate the elastic deformation as well as the plastic one, substituting Eq.(3.4) into Eq.(3.16) finally gives to

$$
\tau . P E E Q=\frac{E}{3(1-2 v) H} \frac{\xi}{\varepsilon_{y}}
$$

It is highly significant to see that the right side of Eq.(3.17) is an item only related to material properties. That is to say, for any point of interest, crack initiation at it indeed, can be interpreted as a process of material deformation working against material tolerance. Crack initiation therefore can be interpreted as a process as that when a product of the stress triaxiality and local ductility is accumulated sufficiently enough to break the material tolerance, crack initiates. In other words, despite of the beam-column connection overall geometrical size, if the product at any given point is judged over the material tolerance, the critical status reaches. For a convenience, the natural logarithm function is taken on both sides of Eq.(3.17), which finally leads to

$$
\operatorname{Ln}(\tau)+\operatorname{Ln}(\mathrm{PEEQ})=\beta
$$

\begin{tabular}{|c|c|c|c|c|c|}
\hline Beam / Column & Material & Element & $\begin{array}{c}\text { Yield strength } \\
(\mathrm{MPa})\end{array}$ & \begin{tabular}{|c|} 
Tensile strength \\
$(\mathbf{M P a})$
\end{tabular} & \begin{tabular}{|c|}
$\begin{array}{c}\text { Elongation } \\
(\%)\end{array}$ \\
\end{tabular} \\
\hline $\begin{array}{c}\mathrm{H}-600 \times 200 \times 12 \times 25(\mathrm{~B} 6) \\
\square-450 \times 450 \times 19\end{array}$ & \begin{tabular}{|l|}
$\mathrm{SN} 490 \mathrm{~B}$ \\
$\mathrm{BCR} 295$ \\
$\mathrm{SN} 490 \mathrm{~B}$ \\
$\mathrm{SN} 490 \mathrm{~B}$
\end{tabular} & \begin{tabular}{|c|} 
Beam Flange \\
Beam Web \\
Column \\
Diaphragm $(28 \mathrm{~mm})$ \\
Diaphragm $(32 \mathrm{~mm})$ \\
\end{tabular} & \begin{tabular}{|l|}
362 \\
425 \\
420 \\
307 \\
302 \\
\end{tabular} & \begin{tabular}{|c|}
516 \\
553 \\
504 \\
498 \\
496 \\
\end{tabular} & $\begin{array}{l}21 \\
23 \\
23 \\
28 \\
31 \\
\end{array}$ \\
\hline $\begin{array}{c}\text { H- } 500 \times 200 \times 10 \times 16(E 5) \\
\square-350 \times 350 \times 12\end{array}$ & $\begin{array}{l}\text { SS400 } \\
\text { BCR295 } \\
\text { SN490B } \\
\text { SN490B }\end{array}$ & \begin{tabular}{|c|} 
Beam Flange \\
Beam Web \\
Column \\
Diaphragm $(19 \mathrm{~mm})$ \\
Diaphragm $(22 \mathrm{~mm})$
\end{tabular} & $\begin{array}{l}293 \\
313 \\
369 \\
319 \\
311\end{array}$ & $\begin{array}{c}448 \\
446 \\
465 \\
510 \\
498\end{array}$ & $\begin{array}{l}30 \\
31 \\
28 \\
29 \\
31\end{array}$ \\
\hline
\end{tabular}

in which

$$
\beta=\operatorname{Ln}\left(\frac{E}{3(1-2 v) H^{\prime}} \frac{\xi}{\varepsilon_{y}}\right)
$$

As shown above, $\beta$ is the parameter dependent to material properties. In addition, since the local stress-strain distribution is

TABLE 1 Material Properties of Steel Used for Test Specimens known much susceptible to its nearby geometrical shape configuration, if the local geometrical shape configuration is not well considered, a connection subassembly theoretically designed having sufficient capability to sustain external load may initiate a crack much early before the anticipated large-scale plastic ductility appears.

\section{FEM SIMULATION}

To validate Eq. (3.18) for judging, evaluating, and predicting crack initiation, FEM analysis is conducted to obtain levels of triaxiality, PEEQ and RI when crack initiates. Test data employed for analysis are provided by a large steel community named Steel Committee of the Kinki Branch of the Architecture Institute of Japan, in which six universities and personnel participated (Inoue, Tabuchi, Nakashima et al. 1997). Objectives of the tests were to reevaluate the plastic deformation capacity of beams in moment resisting frames and to offer improved connection details for providing better ductility. Essential information related to current simulation is shown as the following.

\subsection{Parameters used for simulation}

Major test parameters and their codes for current simulation are listed as

(a) Welding type: field-welding (F) and shop-welding (S)

(b) Beam section and material (see Table 1): H-500 $200 \times 10 \times 16$ (SS400, coded E5) matching a column $\square-350 \times 350 \times 12$ (BCR295)

$\mathrm{H}-600 \times 250 \times 12 \times 25$ (SN490B, coded B6) matching a column $\square-450 \times 450 \times 19$ (BCR295)

(c) Access hole (see Fig. I): conventional type (Z); modified-A (A) and modified-B (B)

(d) Diaphragm and beam flange-thickness-inequality: $3 \mathrm{~mm}$, $6 \mathrm{~mm}$ and $7 \mathrm{~mm}$.

(e) End tab: steel tab (T) and flux tab (K)

Other parameters such as test field and test temperature etc. are omitted because of a difficulty to be simulated. Specimen nomenclature was defined, for example, as SE5A3K, in which ' $S$ ' denoted shop-welding; ' $E 5$ ' denoted material; ' $A$ ' denoted access hole; ' 3 ' denoted thickness-inequality between diaphragm and beam flange and ' $K$ ' denoted end tab.

The T-shaped beam-column connection subassemblies were loaded statically and cyclically with increasing amplitudes of $2 \theta_{\mathrm{p}}$, $4 \theta_{p}$ and $6 \theta_{p}$ sequentially controlled by displacement, in which $\theta_{p}$ is the plastic rotation corresponding to full plastic moment. Each of amplitudes was conducted two complete cycles. If a specimen did not fail after six cycles, additional $6 \theta_{p}$-amplitude cycles would be added until a failure reached.

\subsection{Mesh technique and accuracy verification}

A general-purpose FEM package (ANSYS 1998) is used to investigate and obtain levels of triaxiality, local ductility as well as rupture index when crack initiated. Elements comprised of 8-node bricks and 

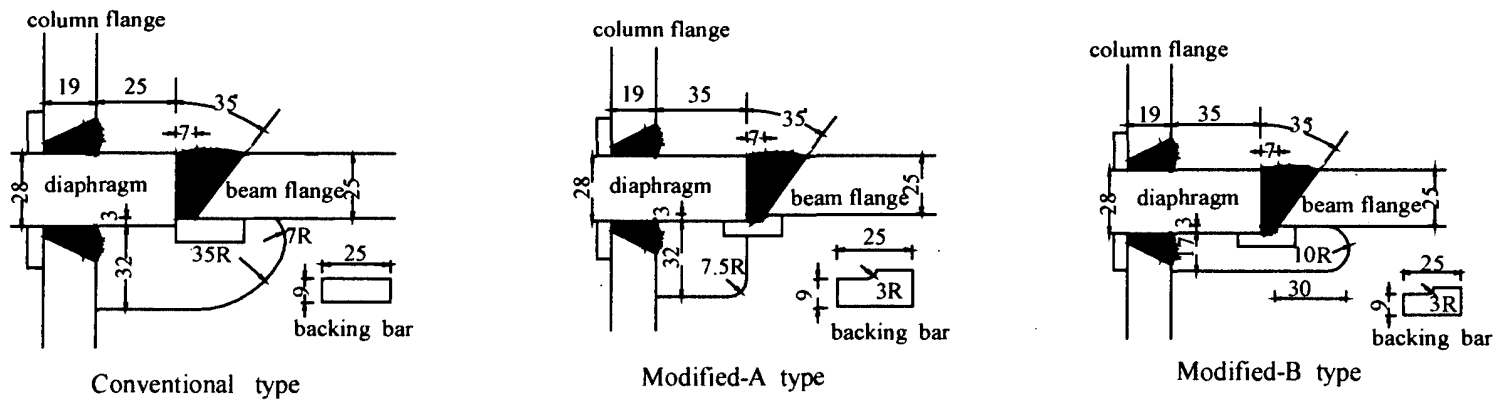

Fig. 1 Different Types of Access Hole Details

6-node prism, are utilized to mesh the half-specimen due to geometrical symmetry. Such a choice is made to save limited node resource and capture local geometrical singularity. As shown in Fig.2, in the vicinity of beam-column interface, the collapsed 8-node brick elements are used to refine the diaphragm, access hole, weld bead, end tab and backing bar etc. The maximum element size is controlled in a range of $1 \sim 9 \mathrm{~mm}$ (see Fig.2 (b)). Away from the vicinity of the beam-column interface, the

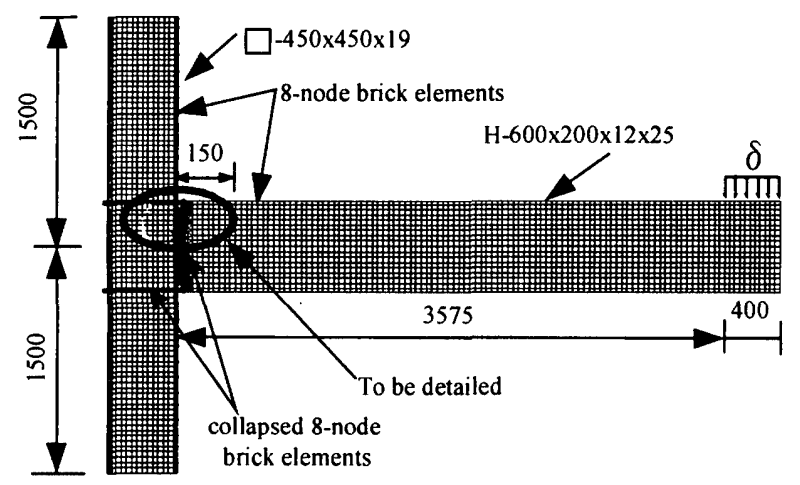

(a) Overall meshing status crack so that they are chosen to obtain levels of those indexes. At both sides of beam flanges, welding attachments are machined to simulate the practical situation. Welded metals in the interface are simplified to exactly match the base metal used in beam flanges. To guarantee each member's (including column, diaphragm, flange, web etc.) material nonlinearity, stress-strain curves obtained from tensile tests (shown as an example in Fig.3) are directly put into programs as basic data for further calculations. On

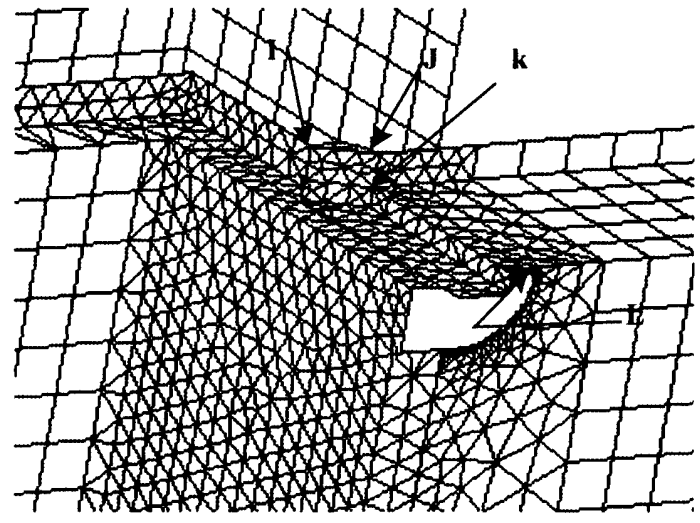

(b) Detailed meshing status

Fig.2 Specimen SE5Z3K Finite-Element Model for Analyzing

maximum mesh size is coarsely set to $32 \mathrm{~mm}$ (see Fig.2 (a)). It should be noted that due to an automatic self-adaptive meshing process, entities with geometrical singularity indeed will be meshed more finely than that defined by the maximum mesh size. As a proof, the after-meshed conventional sickle-shaped access hole (the maximum mesh size controlled up to $1 \mathrm{~mm}$, see Fig. 2 (b)) still keeps a good curved outline as that indicated in Fig.1. Key points marked by $I, J, K$ and $L$ indicate observed locations of

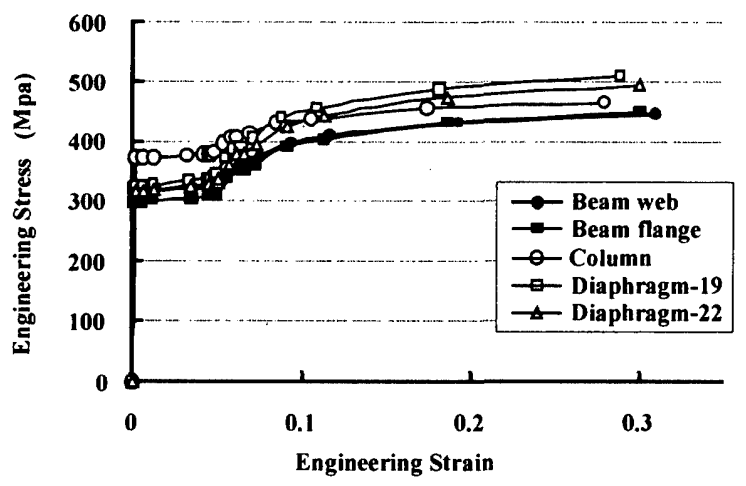

Fig.3 Stress-strain curves of material E5 and BCR295 both column upper end and lower end, pin-supports are assumed. All nodes in a 400-mm length at the beam's free end are coupled to move together with the increasing displacement $\delta$ until the connection plastic rotation (CPR) corresponding to crack initiation reaches. $\mathrm{CPR}$ here is defined as the $\delta p$ known as beam plastic tip displacement divided by the beam length $3775 \mathrm{~mm}$ for calculation. The beam plastic tip displacement here is defined as the loading displacement corresponding to the full plastic moment of the beam

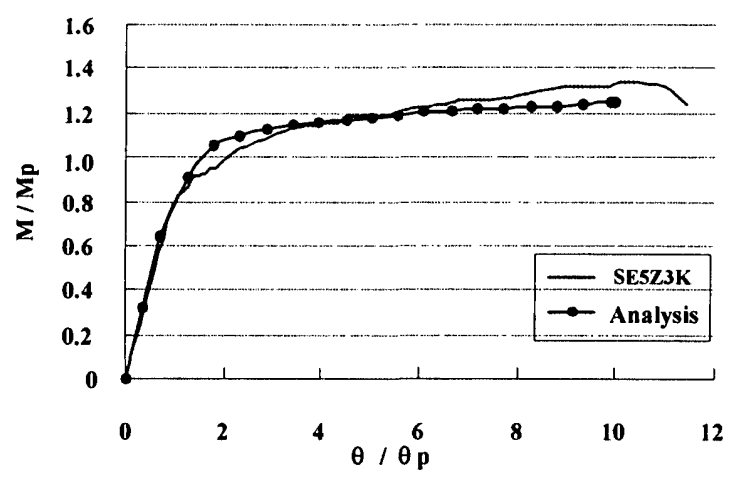

Fig. 4 Moment vs CPR curve 
at the face of the column (El-Tawil et al. 2000).

To verify the current setting, a specimen named SE5Z3K is used to compare with the test. As Fig. 4 shows, the analysis exhibits a plane plastic hardening phase compared with the test. Due to some. simplifications assumed in the process of modeling, the analysis cannot be completely consistent with the test however, it fits the test well in a whole. In addition, local stress-strain convergent status is also attached. As shown in Fig.5, when mesh size is controlled up to a certain extent, for example when the maximum mesh size 4-mm, 2-mm, 1-mm are used to mesh the access hole of specimen SEZ3K (see Fig.2 (b)), stress triaxiality

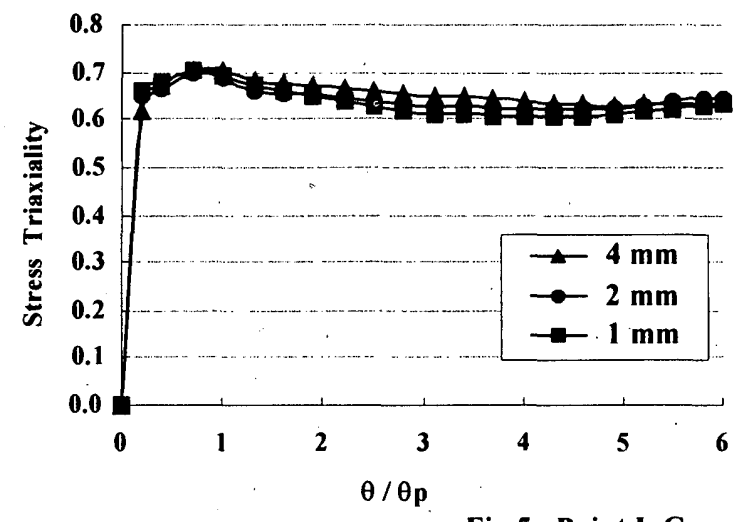

high coefficient of variation 49. This explains why the rupture index is not suitable for evaluating crack initiation. Additionally, the PEEQ index appears a similar tendency with a high coefficient of variation.

\subsection{Significance of coefficient $\beta$}

As shown in Eq.(3.18) and Eq.(3.19), coefficient $\beta$ is related to material properties. Considered that $\xi$ (the first invariant of strain) and $\varepsilon_{y}$ (tensile yield strain) are comparable with each other and, as mentioned in section $3, \xi$ converges when plasticity

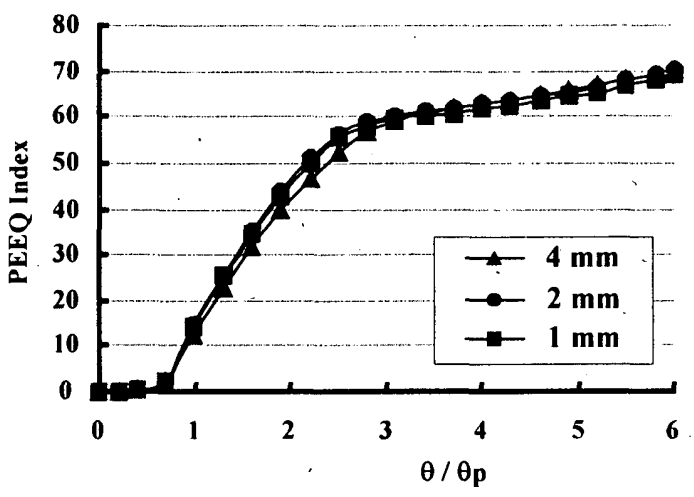

and PEEQ index growing curves at key point $\mathrm{L}$ converge well. In other words, if the maximum mesh size is controlled small enough to grantee an acceptable accuracy, over-refined meshing does not provide obvious accuracy improvement.

\section{NUMERICAL RESULTS AND ANALYSIS}

Table 2 shows the computational results. The given specimen number, crack initiation location and the corresponding loading amplitude were all recorded in the corresponding references (Inoue, Tabuchi, Nakashima et al. 1997). Values in the table indicate their levels when crack initiated. Clearly, most specimens had a crack initiation at loading amplitude $4 \theta \mathrm{p}$. Since locations of crack initiation were given by way of verbal descriptions .without definite coordinates, the maximum response values around key points indicated in Fig.2(b) therefore are considered responsible. At the bottom of this table, average value $\mu$, standard deviation $\sigma$ and coefficient of variation (C.O.V) are summarized for a convenience of comparison. Fig.6 shows the distribution status of the rupture index for all specimens. It is clear that in an average, all specimens cracked with a rupture index 107.0, a standard deviation 52.7 , giving a
TABLE 2 Index Level Corresponding to Crack Initiation

\begin{tabular}{|c|c|c|c|c|c|c|c|c|}
\hline \multirow[b]{2}{*}{ Specimen } & \multirow{2}{*}{$\begin{array}{c}\text { Given } \\
\text { Number }\end{array}$} & \multicolumn{7}{|c|}{ Crack initiation } \\
\hline & & $\tau$ & PEEQ & $\operatorname{Ln}(\tau)+\operatorname{Ln}($ PEEQ $)$ & RI & $\xi / \varepsilon_{y}(x 0.1)$ & Position & Load \\
\hline \multirow{2}{*}{ SE5Z6K } & \multirow{2}{*}{2,4} & 0.51 & 63.04 & 3.48 & 136.21 & 2.05 & $\mathrm{~S}$ & $4 \theta_{0}$ \\
\hline & & 1.02 & 36.57 & 3.62 & 168.18 & 4.25 & $\bar{W}$ & $4 \theta_{0}$ \\
\hline SE5A6K & $6,10,11 *$ & 0.69 & 23.27 & 2.77 & 65.11 & 2.78 & $\overline{\mathrm{W}}$ & $4 \theta p$ \\
\hline \multirow{2}{*}{ SE5B6K } & \multirow{2}{*}{$13,15 *$} & 0.92 & 18.76 & 2.85 & 74.46 & 4.16 & $S$ & $6 \theta p$ \\
\hline & & 0.69 & 23.27 & 2.77 & 65.11 & 2.73 & $\bar{W}$ & $4 \theta p$ \\
\hline \multirow{2}{*}{ SE5Z3K } & \multirow{2}{*}{1,3} & 0.62 & 64.03 & 3.69 & 163.40 & 2.39 & S & $4 \theta_{0}$ \\
\hline & & 0.51 & 26.35 & 2.61 & 56.97 & 2.11 & $\bar{W}$ & $4 \theta p$ \\
\hline SE5A3K & $5,7,8 *$ & 0.92 & 39.44 & 3.59 & 155.76 & 3.87 & $\bar{W}$ & $4 \theta p$ \\
\hline \multirow{2}{*}{ SE5B3K } & \multirow{2}{*}{12,14} & 0.65 & 29.40 & 2.94 & 77.48 & 2.60 & W & $4 \theta p$ \\
\hline & & 0.55 & 62.72 & 3.53 & 142.25 & $2: 23$ & $S$ & $6 \theta p$ \\
\hline \multirow[b]{2}{*}{ SB6Z7K } & \multirow[b]{2}{*}{10} & 1.05 & 32.27 & 3.52 & 156.15 & 6.15 & W & $4 \theta p$ \\
\hline & & 0.92 & 48.04 & 379 & 191.62 & 3.20 & $\mathrm{~S}$ & $4 \theta_{0}$ \\
\hline \multirow{2}{*}{ SB6A7K } & \multirow{2}{*}{$22,24,26$. } & 0.93 & 30.23 & 3.34 & 122.82 & 3.99 & $\bar{W}$ & $4 \theta_{0}$ \\
\hline & & 1.17 & 20.56 & 3.18 & 119.62 & 5.07 & $\mathrm{~S}$ & $4 \theta p$ \\
\hline \multirow{2}{*}{ SB6B7K } & \multirow{2}{*}{$34,36,38$. } & 0.67 & 19.23 & 2.55 & 52.38 & 3.15 & W & $4 \theta_{\mathrm{p}}$ \\
\hline & & 1.06 & 13.93 & 269 & 67.93 & 4.50 & $\mathrm{~S}$ & $4 \theta p$ \\
\hline SB6Z3K & 9 & 0.84 & 33.38 & 333 & 11721 & 3.75 & $\bar{W}$ & $4 \theta p$ \\
\hline SB6A3K & $21,23,25$ & 1.15 & 33.44 & 3.65 & 18748 & 4.72 & $\bar{W}$ & $4 \theta_{0}$ \\
\hline SB6B3K & $33,35,37 \bullet$ & 1.08 & 25.93 & 333 & 13135 & 2.86 & $\bar{W}$ & $4 \theta_{p}$ \\
\hline SB6Z7T & $2,4,6,812$ & 1.09 & 5.08 & 171 & 26.11 & 3.62 & W & $4 \theta \mathrm{p}$ \\
\hline SB6A7T & 18,20 & 0.63 & 19.68 & 251 & 5041 & 3.21 & $\bar{W}$ & $4 \theta p$ \\
\hline SB6B7T & 30,32 & 0.50 & 12.07 & 180 & 25.67 & 2.85 & W1 & $4 \theta p$ \\
\hline \multicolumn{2}{|c|}{ standard deviation $\sigma$ /average $\mu$} & $0.23 / 0.83$ & $16.2 / 30.9$ & $0.57 / 3.06$ & $52.7 / 107.0$ & $1.0 / 3.47$ & & \\
\hline \multicolumn{2}{|c|}{ C.O. $V=100 . \sigma / \mu$} & 28 & 52 & 18 & 49 & 29 & & \\
\hline \multirow{2}{*}{\multicolumn{3}{|c|}{$\begin{array}{l}\mathrm{W}=\text { toe of weld at beam flange tip } \\
\text { (corresponding to Point I or J) }\end{array}$}} & $\begin{array}{l}\mathrm{S}=\text { toe of we } \\
\text { (correspondi }\end{array}$ & $\begin{array}{l}\text { Id access hole } \\
\text { ng to Point } L \text { ) }\end{array}$ & \multirow{2}{*}{\multicolumn{4}{|c|}{$\begin{array}{l}W_{1}=\text { edge of slit between beam flange and end tab } \\
\text { (corresponding to Point } J \text { ) }\end{array}$}} \\
\hline & & & - - see $\mathrm{Nak}$ & shima et al. (1997) & & & & \\
\hline
\end{tabular}


black bold straight line plotted in this figure is interpreted as the critical line of crack initiation. For any given point in a connection subassembly, if the calculated value $\beta$ (for example, corresponding to $4 \theta \mathrm{p}$ load amplitude) finally turns out locating at upper side of

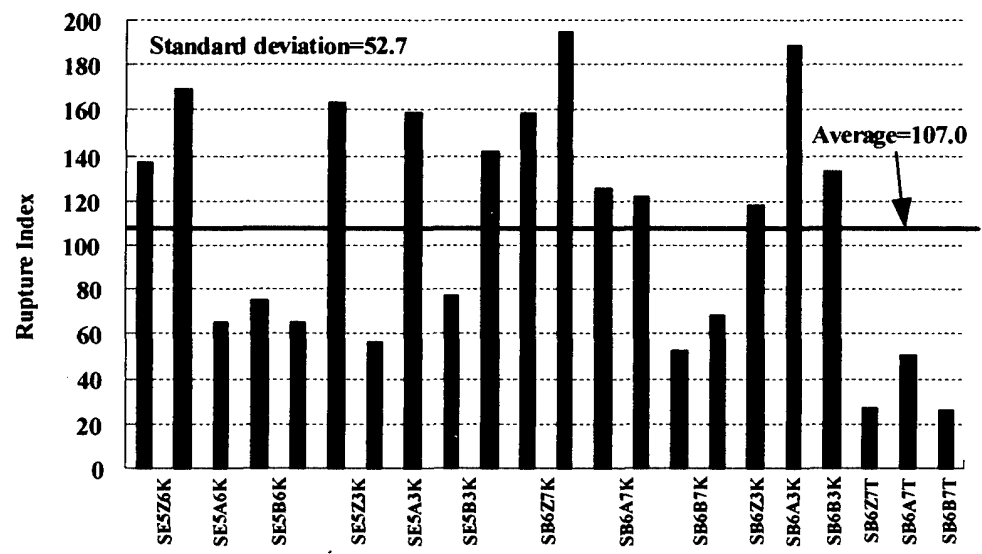

Fig.6 Status of Rupture Index Distribution

the line, such a point is judged higher a susceptibility to initiate a crack than the critical. In other words, regarding to this point, current configuration is much susceptible to crack initiation. The designed load needs to be decreased; Inversely, if the calculated data turn out to locate at lower side of the line, the susceptibility to crack initiation can be judged lower than the critical. The corresponding configuration is less susceptible to crack initiation. The designed load is currently allowable. It is interesting to see that most dots related to modified-B configurations locate under the critical line, which coincides with test results that this type of connection was less susceptible to crack initiation.

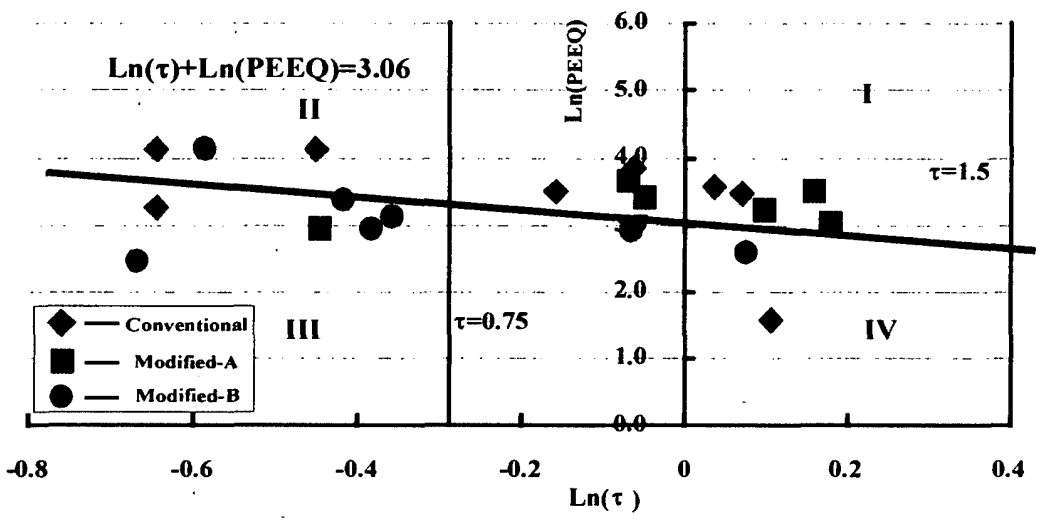

Fig.7 A Relationship between Triaxiality and PEEQ( $\beta=3.06)$

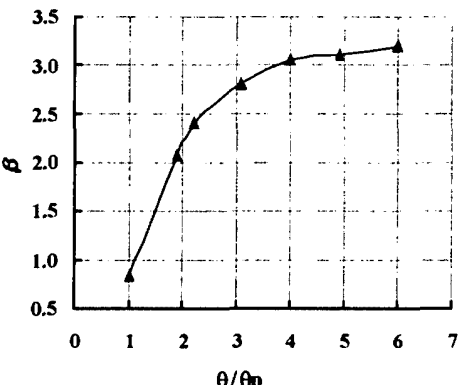

(a)

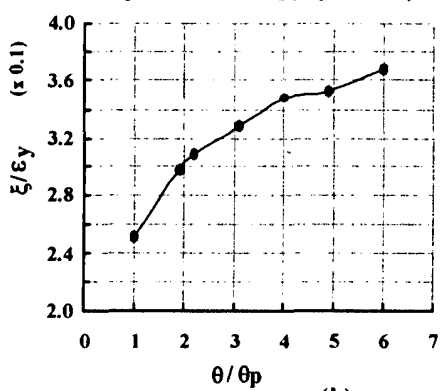

(b)
Fig.8 Coefficient Growing Tendency with Increasing CPR
To indicate the tendency of high triaxiality to limit the ductility and increase the propensity for fracture, LeMaitre (1996), Barsom and Rolfe (1988) pointed out that high triaxiality $(0.75<\tau$ $<1.5$ ) could cause a large reduction in the rupture strain of metals. Very high triaxiality $(\tau>1.5)$ could result in brittle behavior. Followed with these definitions, Fig. 7 is divided into 4 areas. Boundaries are the bold line, line of $\tau=0.75$ and line of $t=1.5$. Using this figure, if the calculated data turn out to distribute in area-IV, crack initiation mode is judged 'brittle' because of a tendency of high triaxiality and low local ductility. Similarly, if the calculated data turn out to distribute in areas-II, crack initiation mode is judged 'ductile' because of a tendency of low triaxiality and high local ductility. It is highly significant to see that there are about $70 \%$ data from the conventional and modified-A subassemblies locating in area-I and areas-IV, showing a failure mode of high triaxiality and low local ductility. Relatively, $80 \%$ data from the modified-B subassemblies locate in area-II and area-III, failed with low triaxiality and high ductility. Such a distribution indicates that modified-B subassemblies have a tendency to show better ductility than the other two subassemblies when crack imitates.

In summary, current analysis revealed that $\beta$-criterion could be used for judging, evaluating and predicting crack initiation susceptibility as well as failure mode.

\section{2 $\beta$ applied to connection load design}

For a convenience of further comparison, values of $\beta$ with the increasing CPR are similarly obtained when crack initiation locations keep unchanged. In detail, as shown in Table 2, all data are associated with crack initiation when loading amplitude (about $4 \theta \mathrm{p}$ ) reached. At other loading stages (for example, at stage of $1 \theta p, 2 \theta p, 3 \theta p, 5 \theta p$ and $6 \theta p$ ), responses of $\beta$ can be accordingly obtained. To make the process of judging, evaluating and predicting easier to operate, the growing tendency of $\beta$ against the increased CPR is plotted. In addition, growing graph of $\xi / \varepsilon_{\mathrm{y}}$ is also attached. As shown in Fig.8, $\xi / \varepsilon_{\mathrm{y}}$ grows flatly while $\beta$ does not. $\xi / \varepsilon_{\mathrm{y}}$ increases from 0.25 to 0.37 in the range of $\theta p \sim 6 \theta p$, which again demonstrates that $\xi$ converges when plasticity develops.

Fig.9 shows an example of $\beta$ applied to connection load design. In this figure, a new connection detail and its growing curves at key points are used for demonstration. Because test data of this connection are not available currently, key points indicated in Fig.2(b) therefore are assumed as locations of crack initiation. The new specimen is named SB6S7K, which involves a streamline access hole (Qi and Mimura, 2002). It can be seen that in the current configuration, point $I$ and point $\mathrm{L}$ are much less susceptible to crack initiation because their curves locate under the critical line of crack initiation. However, the curve of point $\mathbf{J}$ intercepts the critical line. If load amplitude of $4 \theta p$ is thought sufficient enough to initiate 

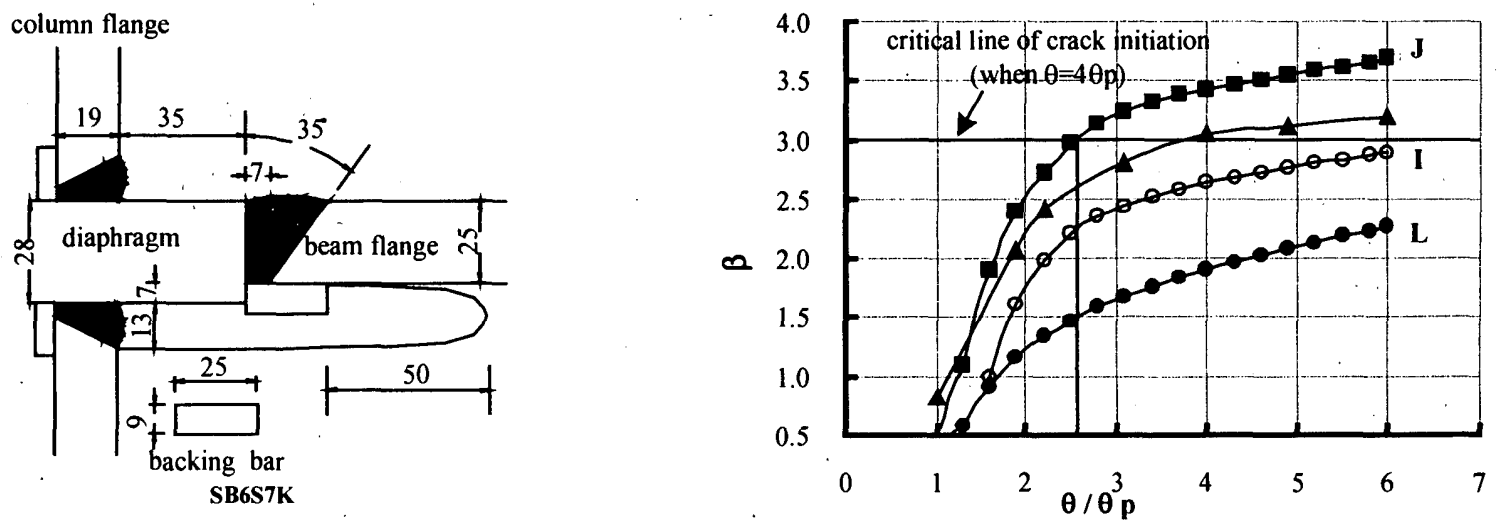

Fig.9 An Example for Evaluating, Judging and Predicting

a crack, the equivalent load for design is judged as much as only $2.60 \mathrm{p}$, which throws a doubt on validity of the streamline access hole design. For a convenience of further explanation, $\beta$-growing curve (indicated by marks with- $\Lambda$ ) in Fig.8 is introduced in. If measures are adopted to push the J-curve beneath the curve with$\boldsymbol{\Lambda}$, the load-bearing ability of this subassembly therefore can be much improved: A measure suggested is to adopt a streamline or circular diaphragm-to-flange transition.

In summary, information on how to conduct connection load design as well as how to identify key point that needs adopting measures to strengthen has been provided.

\section{DISSCUSSION AND CONCLUSIONS}

Serving as additional and further explanations, issues related to loading amplitude and welded material strength mismatch will be discussed here. In current simulation, monotonic loading instead of cyclic loading is used to obtain indexes of crack initiation. Reasons for such a treatment are given as follows: Firstly, loading amplitude during the test was increased from $2 \theta_{p}$, $4 \theta_{p}$ and $6 \theta_{p}$ sequentially (two cycles each), most specimens showed crack initiations after 4 cycles. Connections fractured after 6 cycles. This excludes a possibility of fatigue crack initiation. Crack initiation therefore is thought caused by loading amplitude and number of cycles; Secondly, suggested by Kato et al (1968), a cyclic loading can be equivalently transformed into a monotonic loading. Investigating the hysteresis loops of moment-rotation reported in the literatures (Inoue, Tabuchi, Nakashima et al. 1997.) we found that loops turned out to be close and stable with a good symmetry, Baushinger effect was hardly seen. After finishing the transforming process we also found that equivalent monotonic loading amplitude showed a bit higher than that of $4 \theta p$ indicated in the cyclic loops (most connections had a crack initiation at loading amplitude $4 \theta p$ after four cycles, also see Table2). Due to a 'delay' of crack observation (for example, Tabuch et al. (1997) considered a crack length $2.5 \sim 5 \mathrm{~mm}$ as their start point of crack propagation), loading amplitude therefore needs to withdraw some degree. As a result, the $4 \theta \mathrm{p}$-amplitude monotonic loading is employed as a best choice.

However, explanation given above does not exçlude concerns like that the equivalent monotonic loading guarantees that local stress-strain field is not affected by cyclic loading even with small number of cycles. It is true that local peak stress-strain responses are crucial to obtain triaxiality as well as PEEQ index to evaluate crack initiation. Fundamental work of Cofie et al. (1985) however shows that cyclic inelastic stress-strain curve for metals with high stacking fault energy (for example, steel) acts as a stable reference curve to which the metal tries to return regardless of previously applied loading history. In other words, regardless of previous history and the number of constant strain amplitude cycles, the peak stress/strain will stabilize at a value corresponding to that on the cyclic stress-strain curve for that amplitude. Say it in current analysis, due to static loading, the second path of each loop of stress-strain (say, skeleton curve) at given point should give an accurate representation of the first state of stress and strain at a stage during the cyclic deformation process corresponding to $2 \theta p / 4 \theta p / 6 \theta p$ amplitude. In other words, levels of peak stress /strain are determined by loading amplitudes to a large extent if small number of cycles does not tend to destabilize stress-strain loops. In current simulation, small number of cycles may have affected the skeleton of stress-strain curve however, as a disproof, tests conducted by Saito et al. (2001, see Fig.8) showed that, for welded beam-column subassemblies with different beam length loaded with similar $2 \theta p / 4 \theta p / 6 \theta p$ cycles, strain distribution in beam flanges near the column face showed no obvious differences between two cycles with the same loading amplitude. Therefore, effect on stress-strain loops from small number of cyclic loading is judged minor.

The other issue is the welded material strength mismatch. When modeling a connection subassembly, the welded material is simplified exactly matching the base metal. It is true that for any key point, material strength mismatch can affect the stress/strain response history, however, according to An et al. (2001, see Fig.20) who used the equivalent plastic strain $\varepsilon_{\mathrm{e}}{ }^{\mathrm{p}}$ and triaxiality to evaluate crack initiation of round bars with yield stress mismatch $\mathrm{S}_{\mathrm{T}}(\mathrm{y})$ of 1.81 and tensile strength mismatch $\mathrm{S}_{\mathrm{T}}(\mathrm{T})$ of $1.41\left(\mathrm{~S}_{\mathrm{T}}(\mathrm{y})\right.$ and $\mathrm{S}_{\mathrm{T}}(\mathrm{T})$ were ratios defined as yield stress and tensile strength of welded material $\mathrm{H} 80$ divided by corresponding ones of the base metal $\mathrm{H} 50$ ), that strength mismatch tended to scatter critical curve of crack initiation was hardly seen. In other words, strength mismatch may affect the triaxiality and local ductility individually therefore affect the relative ratio triaxiality to PEEQ index and vice versa, however, it does not affect their product $\boldsymbol{\beta}$ corresponding to crack initiation. Moreover, valuable information given by Nakashima et al. (1998) proves that welding material used to 
practical connection design generally shows only a bit higher yield strength than the base metal (in current simulation, welding material YGW-11 with 390/490 MPa for the yield/tensile strength matching for example $362 / 516 \mathrm{MPa}$ for the yield/tensile strength of beam flange respectively, see Tablel), strength mismatch therefore if has any deleterious effect, may slightly affect judging or evaluating the likelihood of crack initiation mode.

To be strict, macro-scale crack initiation indeed, is not a concept of point but a concept of small volume, which is analogous to concept void defined in micro-scale fracture mechanics (Rice and Tracy 1969). Crack cannot initiate at a point. The concept of point is used in this simulation only for a convenience of obtaining indexes demanded. Accordingly, real crack initiation can be discussed only when a certain of damaged volumes or pre-crack length is defined. As a result, an occurrence of crack observation 'delay' mentioned previously indeed, is mechanically helpful to validate current evaluation of macro-scale crack initiation. However, defining a crack length of $2.5 \sim 5 \mathrm{~mm}$ as crack initiation is too rough even for macro-scale crack initiation. Although the authors tried to modify this 'roughness' by withdrawing loading amplitude some degree, such a modification is surely difficult to evaluate because currently no a commonly accepted benchmark exists. Consequently, crack initiation mentioned in this paper is a concept of that when crack length is perceptible by naked eyes, which necessitates a more precise measurement in future tests.

To summarize, due to some simplifications and other possible factors unconsidered, crack initiation critical level 3.06 obtained in this study indeed, is a quality having scattering. Due to limitations, deleterious effect from the scattering is currently difficult to evaluate, which necessitates a deeper research. Despite of this, this paper establishes a fundamental and useful way for quantitative analysis of fracture design on welded beam-column connection in the future. Briefly, conclusions can be drawn as follows:

1. The existing rupture index is proved unqualified for giving critical value to evaluate welded beam-column connections.

2. A new definition of relationship between stress triaxiality and local ductility has been suggested. Such a definition is qualified for judging, evaluating and predicting crack initiation by investigating triaxiality and local ductility at key points in the welded beam-column connections. It is also valid for determining connection load-bearing ability.

3. Due to simplifications, crack initiation level obtained is a quality having scattering, which necessitates a future work. Despite of this, this paper establishes a fundamental and useful way for quantitative analysis of fracture design on welded beam-column connections in the future.

\section{REFERRENCES}

An, G, Yoshida, S., Praunseis, Z., Ohata, M., and Toyoda.-M. (2001) "Effect of strength mismatch and dynamic loading on criterion for ductile crack initiation." Journal of the Society of Naval Architects of Japan, No.189, 375-386. ( in Japanese)

ANSYS (1998). Structure analysis guide release5.7 <http://www.ansys.com>

Barsom, J.M., and Rolfe, S. T. (1987). Fracture and fatigue control in structures. Prentice Holl, Englewood Cliffs, N.J.
Cofie, N.G, and Krawinkler, H. (1985). "Uniaxial cyclic stress-strain behavior of structure steel." J. Mech. Engrg., ASCE, 111(9), 1105-1120.

El-Tawil, S., Mikesell, T., and Kunnath, S. K. (2000). "Effect of local details and yield ratio on behavior of FR steel connections." $J$. Struct. Engrg., ASCE, 126(1), 79-87.

Kato, B., and Akiyama, H. (1968). "The ultimate strength of the steel beam-column." Transition of the Architectural Institute of Japan, No.151, 15-20. (in Japanese)

Kuwamura, H., and Akiyama, H. (1994). "Size effect on fibrous crack initiation strain." Journal of Structural Construction Engineering, $A I J$, No.458, 119-125. (in Japanese)

Kuwamura, H., and Yamamoto, K. (1995). "Criterion for ductile crack initiation in structural steels under triaxiality stress state." Journal of Structural Construction Engineering, $A I J$, No.477, 129-135. (in Japanese)

Lemaitre, J. (1996) A course on damage mechanics, Springer, Berlin.

Hancock, J. W. and Mackenzie, A. C. (1976). "On the mechanisms of ductile failure in high-strength steels subjected to multi-axial stress-states." Journal of Mech. Phys. Solids, Vol. 24, 147-169.

Inoue, K., Kohzu, I., Tateyama, E., and Tabuchi, M., et al. (1997). "Full-scale test on plastic rotation capacity of steel wide-flange beams connected with square tube steel columns (Part I: Tesi plan and pilot test)." Steel Construction Engineering, 4(16), 27-42. (in Japanese)

McClintock, F. A. (1967). "A criterion for ductile fracture by the growth of holes." J. Appl. Mech., 35, 363-371.

Nakashima, M., Suita, K., Morisako, K., and Maruoka, Y. (1998). “ Tests of welded beam-column subassemblies I: Global behavior" $J$. Struct. Engrg., ASCE, 124(11), 1237-1244.

Nakashima, M., Tateyama, E., Morisako, K., and Suita, Y. (1997). "Full-scale test on plastic rotation capacity of steel wide-flange beams connected with square tube steel columns (Part III: Test for specimens of shop-welding type with a beam section of

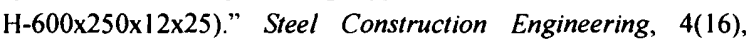
59-74 (in Japanese)

Ohata, M., Minami, F., Fujita, S., Hashimoto, M., and Toyoda, M. (2000)."Ductile crack growth behavior of structural steels under cyclic loading (Part l: Brittle fracture evaluation of steel components subjected to large scale cyclic loading)." Journal of the Society of Naval Architects of Japan, No.188, 679-689. ( in Japanese)

Qi, W., and Mimura, H. (2002), "Streamline geometry optimization in beam-column connection." J. Struct. Engrg., ASCE, 128(6), 829-832.

Rice, J. R., and Tracey, D. M. (1969). "On the ductile enlargement of voids in triaxial stress fields." J. Mech. And Phys. of Solids, Vol. 17, 201-217.

Saitoh T., Tateyama, E., and Suita, K. (2001) "Cyclic behavior of welded beam-to-column with different beam length (Part II: strain behavior)." Summaries of Technical Papers of Annual Meeting, C-1, AIJ. 811-812. (in Japanese)

Schafer, B.W., Ojdrovic, R.P., and Zarghamee, M.S. (2000). "Triaxiality and fracture of steel moment connections." J. Struct. Engrg., ASCE, 126(10), 1131-1139.

Tabuchi, M., Morita, K., Tanaka, T., and Kamba, T. et al. (1997). "Full-scale test on plastic rotation capacity of steel wide-flange beams connected with square tube steel columns (Part II: Test for specimens of shop-welding type with a beam section of

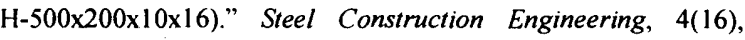
43-55. (in Japanese)

Taira, S. (1976). Modern plastic mechanics, Tokyo, Japan. (in Japanese) 


\section{和文要約}

\section{1. 序論}

ノースリッジ及び神戸地震後、柱一はり接合部の脆性破壊防 止の研究が精力的に行われている。その破壊の要因は、柱一は り接合部における破壊感受性に関係がある忘力三軸度、および 局部延性と考えられる。

応力三軸度は破壊力学におけるボイドの成長、融合に強く関 係する重要な要素であると言われ、金属の延性破壊の場合、高 い応力三軸度は急激な累積損傷、及び破壊ひずみを大幅に低減 することが指摘されている。さらに、破壊部分における降伏、 及び塑性化による応力上昇の制限があり、塑性域における応力 三軸度と局部延性の破壊能力を知る事は重要である。

現在まで国内では，応力三軸度と局部延性を用いてき裂発生 限界を定義する研究はまだ少ない。本論文では弾塑性理論を用 い、一つの新しい忘力三軸度と局部延性との理論関係を推定し た。実験結果を有限要素法による結果と合わせる事により、き 裂発生に関する破壊限界值を決め、最後にその有効性を示した。

\section{2. 応力三軸度と局部延性との関保の現状}

応力三軸度と局部延性の定義式はそれぞれ(2.1)，(2.4)に示さ れる。これら二つの関係を初めて結びつけたのは，El-Tawil 等 で破壊指数として(2.6)に示した。(2.6)式は体積膨張係数式(2.7) 一破壊時ひずみ式(2.8)から修正したものである。これらの式は 破壊傾向を比較することは出来るが，破壊限界値を与えるもの ではない。

\section{3. 応力三軸度と局部延性の関媇の新提案}

微小変形におけるフックの法則を(3.1)〜 (3.3)に示すことに よって静水応力を(3.4)で得られる。式(3.5)から式(3.10)までは ひずみ増分理論によって、式(3.5)が弾塑性範囲に適用すること を証明した。続いて、局部延性の式(2.4)を微分し、ひずみ増分 理論で定義される局部延性と相当応力との関係を式(3.11)に代 入して方程式の両端を積分することにより、破壊限界を提案す る式(3.18)が得られる。ここで, 破壊限界とはき裂発生限界を 意味する。

4. F EMシミュレーション

本節では、井上、田淵、中島等の実大実験結果を有限要素法 による結果と合わせる事により、破壊限界に関する応力三軸度 と局部延性との関係式中の未知数 $\beta$ を決定する。

\section{1 解析パラメメタ}

解析に用いたパラメータは以下の通りである。

(a) 溶接場所

(b) はり部材の鋼種と断面 (Table1 参照)

(c) スカラップの形状 (Fig.1 参照)

(d) はりフランジとダイヤフラムの板厚差

(e) エンドタブの種類

\section{2 解析方法}

本解析には汎用ソフト，ANSYS を用いた。要素分割は Fig.2 に示すように、溶接接合部近辺は 1 9 mm の 6 節点立体要素に 分割し、その他の部分は $32 \mathrm{~mm}$ の 8 節点立体要素とした。また、 Fig. 2 に示す I,J,K,L はき裂発生位置を示す。解析に用いた龬の 応力一ひずみ関係は構成要素ごとにそれぞれの素材試験に基づ き Fig. 3 に示す。

解析方法ははり端部の変形量を制御するもので、最大 $6 \theta \mathrm{p}$ ま
での単調載荷とした。実験で得られているき裂発生個所とその ときの変形量に対応する点での忘力三軸度、及び局部延性值を FEM 解析で求めるものである。本解析の精度は、曲げモーメン トとはりの回転角関係を実験值と比較することにより (Fig.4 参 照), 局部の応力とひずみとの収束状況も(Fig.5 参照) 確認した。

\section{5. 解析結果とその考察}

Table2 に解析結果の一覧を示す。同表には試験体番号、き裂 発生場所、その時の荷重值、及び FEM 解析で得られた忍力三軸 度 $(\tau)$ 、局部延性（PEEQ）、破壊指数（RI）等を示す。Fig.6 に示すように、RI は大きいなばらつきを有し、破壊を評価する には十分な信頼性を与えるものではない。

\section{5. $1 \beta$ について}

(3.19)式で定義した新しい破壊に関する限界值 $\beta$ は Table2 示 す応力三軸度と局部延性值をデータとして回帰分析により求め ると、 $\beta=3.06$ となる。Fig.7 は縦軸に局部延性値、横軸に忍力 三軸度を自然対数として採り、解析値をプロットしたものであ る。図中の太い実線はき裂発生境界を表し、(3.19)式で $\beta=3.06$ としたものである。また， $\tau=0.75 \quad(\ln \tau=-0.28) 、 \tau=1.5(\ln$ $\tau=0.405$ )の細い実線はBarson 等が応力三軸度を基準として破

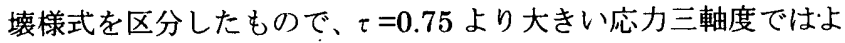
り脆性的な破壊を起こすことを意味する。解析結果では、従来 型と改良A型スカッラプの約 $70 \%$ は $\tau=0.75$ より高い忘力三軸 度区域に分布し、改良 B型の約 $80 \%$ はその境界線より低い領域 に分布している。本論文ではここで提案するき裂発生境界線と Barson 等が提案した 2 本の破壊区分線を用いて、応力三軸度と 局部延性值との関係を考慮して破壊領域を I 〜 IV のプロックに 分けた。例えば、領域 【は低い忘力三軸度、高い局部延性で破 買する延性に近い破壊を起こす領域を意味し、領域IVはそれと 反対に脆性に近い破壊を起こすことを意味する。

\section{5. $2 \beta$ 0応用事例}

$\beta$ 及び式(3.19)に示しているパラメータの CPR（接合部塑性 回転角）の増加による変化傾向を Fig.8 に示す。Fig. 9 は流線型 スカッラプに関する接合部の詳細及びき裂発生場所によって得 られる $\beta$ と CPR の関係である。図に示すように I 点、J 点はき 裂発生境界線の下方に分布し、J 点の成長線はき裂発生境界線 と $2.6 \theta \mathrm{p}$ で交差している。このことは, J 点では約 $2.6 \theta \mathrm{p}$ でき 裂が発生することを意味する。

\section{6. 討論と結論}

繰返し負荷下の応力ーひずみ関係は加藤らの研究から、その スケルトン部を加算する方法で単調負荷下の応カーひずみ関係 に置き換えることができる。本研究は、き裂発生を問題にして いる事、および実験で観察されたき裂は発見時以前に既に生じ ていたと考えられる事より、本研究ではスケルトン部の加算を 考慮していない。一方、溶接金属と母材とのミスマッチは、き 裂発生に殆ど影響を与えないという見解から、母材と溶接部の 材料特性は同一とした。

本研究の主な結論は以下の通りである。

1）柱一はり接合部におけるき裂発生の評価式(2.6)では実験結 果を十分に説明できない。

2）本論では応力三軸度と局部延性を考慮したき裂発生評価式 (3.18)を提案した。提案式により柱一はり接合部におけるき裂 発生個所，及びその発生回転角度を評価することが出来る。

3）本研究で得られたき裂発生限界值は、ばらつきを含んでいる ものである。 